\title{
Analysis of Korean Viseme System in Korean Standard Monosyllabic Word Lists
}

\author{
Jaehee Choi ${ }^{\mathrm{a}}$, Keonseok Yoon ${ }^{\mathrm{a}}$, Hyesoo Ryu ${ }^{\mathrm{a}}$, Hyunsook Jang ${ }^{\mathrm{b}}$ \\ ${ }^{a}$ Department of Speech Pathology and Audiology, Graduate College, Hallym University, Chuncheon, Korea \\ ${ }^{b}$ Division of Speech Pathology and Audiology, Research Institute of Audiology and Speech Pathology, Hallym University, Chuncheon, Korea
}

Correspondence: Hyunsook Jang, PhD

Division of Speech Pathology and Audiology, Hallym University, 1 Hallimdaehak-gil, Chuncheon 24252, Korea

Tel: +82-33-248-2218

Fax: +82-33-256-3420

E-mail: hsjang@hallym.ac.kr

Received: April 10, 2017

Revised: June 9, 2017

Accepted: June 25, 2017

\begin{abstract}
Objectives: The purpose of this study was to investigate the speechreading abilities of the Korean population and verify the Korean viseme system by utilizing the Korean Standard Monosyllabic Word List for Adults (KS-MWL-A), a list of words selected in consideration of phonemic balance and frequency of everyday use. Methods: KS-MWL-A words spoken by both male and female speakers were filmed. The speechreading test with no auditory cues was performed on 32 subjects and the percent correct scores of words and phonemes were identified and analyzed using ANOVA. Three positions of phonemes, initial, medial and final, were classified according to a confusion matrix to determine the Korean viseme groups based on a criterion of a $60 \%$ correct response. Results: The results showed that the percent correct score of words was $13.00 \%$. The percent correct scores of phonemes of initial, medial, and final positions were $19.04 \%, 48.26 \%$, and $44.77 \%$, respectively. The Korean visemes were classified as initial phonemes $\left[/ k, k h, k^{\prime}, h,[] /, / n, d, t^{\prime}, t h,(s),[] /, / m, p, p h\right.$,

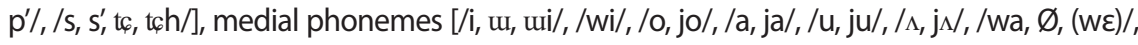
$/ \mathrm{j} \varepsilon, æ, \mathrm{e} / \mathrm{l}$ and final phonemes $[/[], \mathrm{k}, \mathrm{b} /, / \mathrm{n}, \mathrm{d} /, / \mathrm{l} /, / \mathrm{m}, \mathrm{b} /]$. Conclusion: It was revealed that vowels affect both the initial and final position of consonants in the Korean viseme system. Furthermore, the sensitivity to the presence of the final consonant seemed to have the capability to affect the final consonant of the viseme system.
\end{abstract}

Keywords: Speechreading, Lipreading, Viseme, Korean, Korean Standard Monosyllabic Word Lists for Adults (KS-MWL-A) 독화(speechreading)는 시각 정보에 해당하는 화자의 얼굴 및 입 모양을 관찰함으로써 발화 내용을 이해하는 의사소통의 과정(De Filippo \& Sims, 1988; Dodd \& Campbell, 1987; Jeffers \& Barley, 1971; O’Neill \& Oyer, 1981)으로 청각장애인 대다수에게 주된 의 사소통방식으로 널리 사용되고 있으며(Lamoré, Huiskamp, van Son, Bosman, \& Smoorenburg, 1998; Bernstein, Tucker, \& Demorest, 2000), 청력손실의 정도가 심할수록 그 의존의 정도도 커진다. 건청인 역시 일상 속 의사소통에서 독화를 활용하는 것으로 보고 되었으며(Grant, Walden, \& Seitz, 1998; Woll, 2012), 청각장애인과 건청인 모두 독화 수행도에 큰 개인차를 보이는 것으로 나타났다 (Bernstein et al., 2000; Mohammed et al., 2005; Watson, Qiu, Chamberlain, \& Li, 1996).

독화는 또한 화자의 말을 인지하기 위해 청각 단서와 시각 단서
양쪽을 활용하는 의사소통 방식으로 정의됨으로써 시각 단서에만 의존하는 독순(lipreading)과 구별 짓기도 한다(Tye-Murray, 2014). 그러나 Burnham, Campbell, Away와 Dodd (2013)는 시각 정보를 통해 인지되는 것이 결국은 얼굴 움직임이 아니라 발화내용이기 때 문에 독화라는 용어가 독순을 대체하고 있다고 하였다. 독순이나 독화를 통한 말인지의 핵심 원리는 입모양의 기반이 발화내용의 기저구조에 있다는 것이다(Holden \& Owens, 2000).

Fisher (1968)는 연구대상자에게 자음-모음-자음(consonant-vowel-consonant, CVC) 형태의 자극을 시각적으로 확인하게 한 결과, 첫 자음과 마지막 자음에 대한 반응음소군이 서로 차이를 보이는 것을 보고하였으며, 이 연구결과를 바탕으로 얼굴 움직임이 유사 한 말소리 집단이 시각적 음소로 기능한다는 의미에서 'visual'과 'phoneme'을 결합한 독화소(viseme)란 용어를 제안하였다. 독화소 
개념은 말소리의 음소에 대응하는 입술 움직임의 시각적 표상을 의 미하는 동시에 말소리의 구분 가능한 시지각적 최소 단위를 가리킨 다(Chen, 2001; Jackson, 1988; Owens \& Blazek, 1985). 독화소는 전 체 음소수에 비해수가 적으며(Walden, Prosek, Montgomery, Scherr, \& Jones, 1977), 독화 과정에서 동일 독화소군을 구성하는 음소들 간에 발생하는 혼동이 서로 다른 독화소군에 속한 음소들 간에 발 생하는 혼동에 비해 난이도가 높다는 특징이 있다(Chen \& Rao, 1998; Summerfield, 1987).

영어권의 독화소 분류에 관한 연구들은 주로 모음-자음-모음 (vowel-consonant-vowel, $\mathrm{VCV}$ ) 또는 CVC 등의 맥락 조건으로 구 성된 자극에 대한 혼동 행렬을 통해 군집 내 반응률을 기준으로 독 화소를 결정하였으며, 그 결정 기준은 임의적인 것으로 $70 \%$ (Binnie, Jackson, \& Montgomery, 1976; Montgomery, Walden, \& Prosek, 1987), 75\% (Benguerel \& Pichora-Fuller, 1982; Kricos \& Lesner, 1982; Owens \& Blazek, 1985; Walden, Erdman, Montgomery, Schwartz, \& Prosek, 1981), 80\% (Wozniak \& Jackson, 1979) 등 주로 $70 \%$ 이상의 군집 내 반응률을 사용하였다. 특히 맥락 조건에 있어 전후의 모음환경이 자음의 독화소 체계에 지대한 영향을 미치는 것으로 나타났다(Auer \& Bernstein, 1997; Cohen \& Massaro, 1993; Owens \& Blazek, 1985). 가령 'two'의 경우/t/는 /u/를 연상시키는 둥근 형태를 갖지만, 'tea'에서의/t/는/i/를 연상시키는 퍼진 형태를 가지면서 다른 반응음소를 갖게 된다(Cohen \& Massaro, 1993; Owens \& Blazek, 1985). Owens와 Blazek (1985)은 영어 자음 23개 와 모음 4 개를 사용한 $\mathrm{VCV}$ 자극을 비디오로 녹화하여 5 명의 건청 인과 5 명의 청각장애인에게 제시하여 독화소 판정 기준 $75 \%$ 에서 모음 $/ \mathrm{a} /$ 가 자음과 결합할 때 구별 가능한 독화소가 7 개였고 $/ \mathrm{a} /, / \mathrm{N} /$, $/ \mathrm{i} /$ 을 사용했을 때 독화소군 5 개가 공통되는 결과가 나타났으나, 모 음이 /u/였을 때 구별 가능한 독화소는 입술의 움직임이 강한 양순 음/p, b, m/과 순치음/f, v/ 두 가지뿐이었음을 보고하였다. Auer와 Bernstein (1997)은 시각적 혼동이 발생하는 음소들에 대하여 일종 의 독화소 체계인 음소 등가성 분류 체계(phonemic equivalence classes, PECs)를 정리하였으며, 이를 통해 모음환경별 자음의 독화 소 체계에 미치는 영향을 정리하였다.

한국어의 독화소 체계에 대한 연구는 제한적이다(Kim JH, 1992; Kim YW, 1993, 1997; Lee \& Kim, 1991; Lee et al., 2006). Kim (1992) 은 Jeffers와 Barley (1971)의 독화 운동자질에 따른 분류를 사용하 고 말의 음운론적 기초와 시각적 요소를 바탕으로 한국어 독화소 체계를 초성자음 독화소군/ㅂ, 빠, 프, ㅁ/,/人, ㅆ, ㅈ, ㅉ, 치,/ᄃ, 匹, E, ᄂ, 리,/ᄀ, ㄱ, ㄱ, 히 4개, 중성모음 독화소군 / / , , k k,

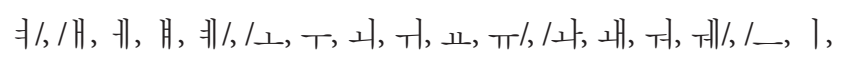

-l/5개, 종성자음 독화소군 /ㅂ, 프, ㅁ/, /ᄃ, E, ㄴ, ㅅ, ㅆ, ㅈ, ㅊ, ㅎ/,/ᄀ, T, ㄱ, 이,/리 4개로 분류하였다. Lee 등(2006) 또한 한국 어의 자음과 모음의 시각적 요소를 조음 자질에 기초하여 분류하 였는데 초성자음을 /ㅂ, 빠, 프, ㅁ/,/ㅅ, ㅆ, ㅈ, ㅉ, ㅊ/,/ /ᄃ, , ㅌ,

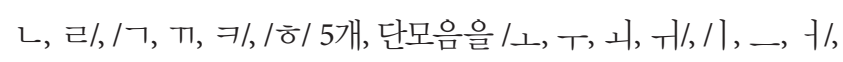
/게, ㅐ//,// / 4 개, 종성자음을/ㅂ, 프, ㅁ/,/ᄃ, E, ㄴ, ㅅ, ㅆ, ㅈ, ㅊ, ㅎ/,/리,/ᄀ, ㄱ, ㄱ, 이 4개로 정리하였다. $\operatorname{Kim}(1997)$ 은 실제 독화 결과를 확인하기 위해 초성자음 19 개를 모음 $/ a /$ 와 결합하고, 단모 음 10 개와 이중모음 12 개를 /h/-V-/g/의 형태로 결합한 자극을 39 명 의 연구대상자에게 시각적으로 제시하였으며, 독화소 기준을 군집 내 정반응률 $60 \%$ 로 설정하고 계층적 군집분석을 통하여 독화소 체계를 분류하였다. 그 결과, 초성자음의 독화소를 /ㅂ, 뻐, 프, ㅁ/, /ᄃ, , E, ㄴ/,/O/,/ᄀ, T, ㄱ, ㄹ, ㅎ/,/人, 씨,/ᄌ, ㅉ, ㅊ/6개로

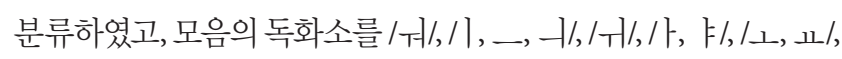

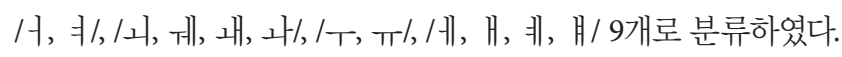
독화소군을 결정하는 판정 기준인 $60 \%$ 변별도는 연구자가 음소의 평균 독화율을 기초로 임의로 설정하였다.

독화소 체계 연구는 독화 수행도 평가 및 훈련을 위한 바탕이 되 며, 국내에서도 한국어 독화소 체계를 기반으로 한 독화 수행도 평 가 및 훈련이 이루어지고 있다(Kuk \& Kang, 1997; Kuk, 1998; Lee, 2010). Kuk과 Kang (1997) 그리고 Kuk (1998)의 연구에서는 Kim (1992)의 독화소 분류체계에 따른 독화 검사를 실시하였으며, Lee (2010)는 Kim (1997)의 독화소 체계를 통해 건청인과 청각장애인 의 독화 정확도를 비교하였다. Kim (1997)은 한국어 독화 정확도에 대해 초성자음은 $38.3 \%$, 이중모음을 포함한 모음은 $61.6 \%$ 로 자음 보다 모음과 이중모음의 정확도가 높으나 모음의 입모양이 독화에 변별적 단서로 작용하지 않으며, 시지각적 혼란이 조음방법이 동일 한 음소에서 보다 조음위치가 동일하거나 인접한 음소에서 더 크 게 나타났음을 보고하였다. Lee (2010)는 전체 음소에 대한 독화 정 확도 $26.17 \%$, 모음 $55.88 \%$, 단모음 $44.64 \%$, 이중모음 $63.75 \%$ 로 나 타났음을 보고하였다. $\operatorname{Lim}$ 과 $\operatorname{Sim}$ (2016)은 스마트폰을 통한 독화 훈련의 효과를 평가하는 연구에서 Lee 등(2006)의 독화소 체계를 사용하였으며, $\operatorname{Kim}(1992,2005,2016)$ 은 자신의 독화소 체계에 기 반한 독화기능검사를 개발하였다.

이렇듯 한국어 독화소 체계가 평가 및 훈련에 적용되고 있으므 로 보다 실질적인 독화소 체계에 대한 검증이 필요하다. 즉 실제적 독화 능력을 바탕으로 한국어 독화소 체계를 살핀 Kim (1997)의 연구에서는 자음과 모음을 각각 C-/a/와 /h/-V-/g/ 조건으로 제시 하였는데 이러한 조건들이 자음이나 모음의 조음 운동에 영향을 적게 받는 잇점(Montgomery \& Jackson, 1983)이 있지만, 일상의 의 
사소통 상황에서의 독화 능력을 평가하기 위해서는 다양한 자모음 맥락을 활용할 필요가 있다. 한국어에서도 맥락 조건에 따라 다른 소리로 발음되는 자음을 변이음 또는 이음이라 하며, 맥락에 대한 변수로는 해당 음소가 초성 또는 종성에 위치하는 지와 전후로 유 성음이 오는지의 여부, 특정 후행모음의 유무 등이 관련되는데 이 러한 맥락 조건이 자음의 청각적 특성만 아니라 시각적 특성에도 영향을 미치는가에 관한 문제가 제기될 수 있다. $\operatorname{Kim}(1993)$ 은 자 음을 모음 $/ \mathrm{a} /$ 및 /i/와 결합하여 제시하고 독화소 기준을 $30 \%$ 로 설 정했을 때 자음의 독화소 체계에 변동이 있었음을 보고하였으며, Lee (2010)는 독화 능력이 자모음 환경에 따라 차이를 보일 수 있으 므로 고정된 제시 조건에서 독화 능력을 보는 것의 문제점을 지적 하고 다양한 모음 환경의 필요성을 강조하였다. 또한 Hiki와 Fuku$\mathrm{da}$ (1997)는 독화 능력을 평가할 때 일상 속 대화에서 각 음소마다 출현 빈도수에 상당한 차이가 있음을 고려해야 한다고 하였으며, Auer, Bernstein, Waldstein과 Tucker (1997)는 독화검사를 위한 자 극을 제시할 때 가장 빈번하게 사용되는 자음군을 사용하였다고 밝혔다. Lidestam과 Beskow (2006)는 연구대상자 24명을 대상으 로 자음 독화검사를 실시할 때 단어와 문장에서 가장 많이 사용되 는 자음 18 개를 사용하였음을 보고하였다.

국내 일반적 어음청각검사에서 사용되는 단어인지검사의 단음 절 자료에 관한 연구들에서는 검사 자료가 갖춰야 할 요소들을 일 상회화체에서 사용되는 음소의 대표성, 음소의 균형, 음소에 대한 친숙도 및 시대성 등 4개로 정리하였으며(Byun, Chung, Kim, \& Go, 2005; Kim et al., 2008), 한국표준 일반용 단음절어표(Korean Standard Monosyllabic Word List for Adults, KS-MWL-A; Kim et al., 2008)는 이러한 기준들에 입각하여 총 200 개의 유의미 1 음절 단어로 개발된 목록이다. 본 연구의 목적은 성인을 대상으로 한국 표준 단음절어표를 활용한 독화검사를 실시함으로써 일상 회화에 서 자주 사용하는 음소를 중심으로 다양한 자모음 환경에서 독화 정확도를 살펴보고 그 결과에 따라 한국어 독화소 체계를 초성. 중 성·종성별로 분석하는 데 있다.

\section{연구방법}

\section{연구대상}

본 연구에서 교정시력이 0.8 이상이고 청력이 정상인 성인 32 명(남 19 , 여 13)을 대상으로 독화검사를 실시하였으며, 연구대상자의 평 균 연령은 21.5세(범위: 20-28세)였다. 연구대상자는 GSI 61 (GrasonStadler Inc., Eden Prairie, MN, USA)을 사용한 순음청력검사 결과, 양측 귀모두 $500,1,000,2,000,4,000 \mathrm{~Hz}$ 에서 $20 \mathrm{~dB} \mathrm{HL}$ 이하였다.

\section{검사도구}

본 연구에서 독화검사를 위한 자료로 한국표준 일반용 단음절 어표(Kim et al., 2008)를 사용하였다. 단음절어표는 한국어 회화체 의 출현 음소 빈도 및 친숙도를 고려하여 각 목록 당 50 개씩 총 4 개 목록의 200 개 단어로 구성되어 음절의 위치별로 한국어 초성자음 19 개 중 /리, / ㅉ/을 제외한 17 개, /月/, / 개/, /T//, / 게/를 제외한 중성 모음 17 개, 종성 7 개와 종성이 없는 형태를 의미하는 열린 음절(무 종성) 형태로 구성되어 있다. 독화검사를 위한 영상자료를 제작할 때 방음실 내에서 표준어를 사용하는 20 대 성인 남녀 화자 2 명이 한국표준 단음절어표의 목록 4 개를 자연스럽게 발화하는 모습을 삼성 갤럭시노트 5 (SM-N920S)로 정면 $1.5 \mathrm{~m}$ 거리에서 녹화하였다 (해상도 $5312 \times 2988,30 \mathrm{fps}$ ). 촬영한 영상의 편집은 동영상 편집 프 로그램 Premiere Pro CC (Adobe Systems, San Jose, CA, USA)를 사용하였다(인코딩 해상도 $1920 \times 1080)$. 영상을 편집하는 과정에 서 자극과 자극 사이에 5 초의 간격을 삽입하고 5 초 카운트다운 영 상을 제시함으로써 새로운 자극이 제시될 때마다 연구대상자의 주 의를 환기할 수 있도록 하였다. 목록별 영상자료의 평균 상영시간 은 3 분이었다.

\section{검사절차}

모든 연구대상자는 본 실험에 앞서 연구내용에 대해 상세한 설명 을 듣고 사전 동의서를 작성하였다. 독화소는 말소리의 구분 가능 한 시지각적 최소 단위(Chen, 2001)로 독화검사는 조음운동 시 나 타나는 시각적 특징을 보아 자극 음소를 인지하는 과정(Kim, 1997) 으로 독화 검사를 실시할 때 조용한 공간에서 모니터(Dell 2412M, $1,920 \times 1,200)$ 를 연구대상자의 정면 $1 \mathrm{~m}$ 에 위치시키고 사전에 녹 화한 영상자료를 음성 없이 상영하였다. 연구대상자들에게 화자의 얼굴 또는 입모양을 통해 인지한 단어를 응답지에 받아쓰도록 안내 하였다.

본 실험에 앞서 한국표준 단음절어표에 미포함된 단음절어 5 개 를 녹화한 영상을 연습용으로 제시하여 연구대상자가 자극 사이 에 삽입된 5 초의 간격과 카운트다운 등 독화검사가 이루어지는 절 차에 익숙해지도록 하였다. 본 실험에서는 연구대상자에게 단음절 어 4 개 목록을 무작위 순서로 제시하였으며 연구대상자의 절반(16 명)에게는 남성 화자 영상을, 나머지 절반에게는 여성 화자 영상을 제시하였다. 2 개의 목록을 제시한 후에는 5 분의 휴식시간을 가짐 으로써 피로효과를 방지하고자 하였다.

\section{자료분석}

단음절어 200 개에 대한 독화 정확도로서 단어 정반응률과 음소 
정반응률을 구하였다. 단음절어는한국어 초성자음 16 개와 초성이 없는 형태를 의미하는 무초성 [ ] 1개, 중성모음 17 개, 종성자음 7 개 와 무종성 [ ] 1 개로 나누어 분석하였다. 음소의 경우에는 초성, 중 성, 종성별로 정반응률과 오류 반응음소의 출현율을 구하였고, 이 를 기반으로 혼동 행렬을 작성하였다. 초성자음의 경우 후행모음에 따라 나타나는 반응음소들을 정반응률이 높은 순서대로 반응음 소군에 포함하였으며, 누적 정반응률 $60 \%$ 이상을 기준 $(\mathrm{Kim}, 1997)$ 으로 하였다. $60 \%$ 에 미치지 못하는 경우에는 오류 출현율 $8 \%$ 이상 인 자음까지 포함하였다. 그 후 군집 내 정반응률 $60 \%$ 이상을 기준 으로 초성의 독화소군을 결정하였다. 중성모음과 종성자음의 독화 소군을 결정할 때에도 동일한 기준을 적용하였다.

\section{통계분석}

본 연구의 통계분석에 IBM SPSS version 23 (IBM, Armonk, NY, USA)을 사용하였다. 목표단어와 초성, 중성, 종성 음소별로 독화 정확도의 평균과 표준편차 등의 기술통계를 구하였고, 초성자음 16 개와 무초성 [ ] 1 개, 중성모음 17 개, 종성자음 7 개와 무종성 [ ] 1 개의 독화 정확도에 대해 반복측정 일원분산분석(repeated oneway ANOVA)과 사후분석을 실시하였다. 초성자음의 경우에는 조 음위치에 따라 양순음, 치경음, 경구개음, 연구개음, 성문음으로, 조
음방법에 따라 파열음, 파찰음, 마찰음, 비음으로 분류하여 각 독화 정확도의 평균과 표준편차를 구하였으며, 반복측정 일원분산분석 과 사후분석을 실시하여 조음위치와 조음방법에 따른 초성자음 간 독화 정확도의 차이를 살펴보았다. 중성모음의 경우에는 단모음 과 이중모음, 평순모음과 원순모음, 전설모음과 후설모음으로 분류 하여 각 독화 정확도의 평균과 표준편차를 구하고 대응표본 $t$-검정 (paired $t$-test)을 실시하여 각 분류별 차이를 살펴보았다. 종성자음 의 경우 한국어의 7 종성법에 따른 7 개의 자음과 함께 무종성에 대 한 독화 정확도의 평균과 표준편차를 구하고 반복측정 일원분산 분석과 사후분석을 실시하였다. 본 연구에서 실시한 분산분석에 서 Mauchly 구형성 가정이 충족되지 않은 경우에는 GreenhouseGasser 검증 값을 사용하였으며, 사후분석은 다중비교로 인해 나 타나는 1 종 오류의 증가를 조정하기 위해서 Bonferroni alpha correction을 사용하여 유의도를 검증하였다.

\section{연구결과}

\section{독화 정확도}

성인 32명을 대상으로 한국어 단음절어 200개를 사용하여 독화 검사를 실시하고 독화 정확도를 분석한 결과, 단음절어 전체의 평

Table 1. Confusion matrix of initial phonemes (\%)

\begin{tabular}{|c|c|c|c|c|c|c|c|c|c|c|c|c|c|c|c|c|c|c|}
\hline \multirow{3}{*}{ Stimulus } & \multicolumn{18}{|c|}{ Response } \\
\hline & ᄀ & 77 & 7 & $\overline{0}$ & 0 & ᄂ & $ᄃ$ & ᄄᄄ & E & $\square$ & ㅂ & $\forall$ & 표 & 人 & 从 & x & 双 & ᄅ \\
\hline & k & $k^{\prime}$ & $\mathrm{kh}$ & $\mathrm{h}$ & {[]$^{\dagger}$} & $n$ & $d$ & $t^{\prime}$ & th & $\mathrm{m}$ & $\mathrm{p}$ & $p^{\prime}$ & ph & s & $s^{\prime}$ & tc & tch & $r$ \\
\hline k & 24.0 & 0.9 & 1.7 & 7.8 & 29.6 & 3.8 & 5.4 & 0.2 & 0.4 & 1.9 & 1.6 & 0.0 & 0.7 & 6.3 & 0.0 & 9.7 & 2.8 & 2.8 \\
\hline$k^{\prime}$ & 22.9 & 3.7 & 0.0 & 6.3 & 23.4 & 6.8 & 4.2 & 0.0 & 0.0 & 3.1 & 0.0 & 0.0 & 0.5 & 10.4 & 0.0 & 10.4 & 5.2 & 2.6 \\
\hline kh & 21.9 & 2.3 & 7.8 & 7.0 & 43.0 & 1.6 & 1.6 & 0.0 & 0.8 & 2.3 & 2.3 & 0.0 & 2.3 & 1.6 & 0.0 & 1.6 & 0.8 & 1.6 \\
\hline h & 12.2 & 0.0 & 2.4 & 15.3 & 29.9 & 4.2 & 5.9 & 1.0 & 1.7 & 0.7 & 2.8 & 0.0 & 0.7 & 9.0 & 0.0 & 5.6 & 5.6 & 2.4 \\
\hline [] & 10.8 & 0.4 & 1.3 & 10.3 & 37.7 & 2.8 & 4.6 & 0.0 & 1.3 & 1.5 & 1.7 & 0.0 & 1.1 & 10.0 & 0.1 & 10.8 & 3.6 & 2.0 \\
\hline$n$ & 4.2 & 0.7 & 0.9 & 2.7 & 16.7 & 8.6 & 17.4 & 1.8 & 6.9 & 1.5 & 0.9 & 0.0 & 1.3 & 20.7 & 0.5 & 7.9 & 4.6 & 2.8 \\
\hline$d$ & 6.3 & 0.6 & 1.5 & 4.2 & 16.7 & 7.5 & 20.2 & 2.9 & 4.4 & 1.8 & 1.5 & 0.0 & 1.5 & 14.9 & 0.0 & 8.8 & 3.7 & 2.8 \\
\hline$t^{\prime}$ & 5.2 & 0.5 & 0.5 & 1.0 & 9.4 & 2.6 & 10.9 & 2.1 & 4.7 & 1.6 & 1.6 & 0.0 & 1.0 & 10.4 & 0.0 & 5.7 & 5.2 & 3.65 .0 \\
\hline th & 4.2 & 0.0 & 0.0 & 3.1 & 16.7 & 7.3 & 11.5 & 6.3 & 5.2 & 0.0 & 3.1 & 0.0 & 2.1 & 20.8 & 2.1 & 6.3 & 5.2 & 5.21 .0 \\
\hline $\mathrm{m}$ & 0.5 & 0.0 & 0.2 & 2.4 & 2.2 & 0.0 & 0.5 & 0.0 & 0.0 & 25.2 & 41.6 & 2.6 & 23.6 & 0.2 & 0.0 & 0.0 & 0.0 & 0.5 \\
\hline$p$ & 0.9 & 0.0 & 0.0 & 1.4 & 2.3 & 0.0 & 0.0 & 0.0 & 0.3 & 17.9 & 60.8 & 1.7 & 13.4 & 0.6 & 0.0 & 0.3 & 0.0 & 0.3 \\
\hline$p^{\prime}$ & 1.6 & 0.0 & 0.0 & 4.7 & 0.0 & 0.0 & 0.0 & 0.0 & 0.0 & 9.4 & 48.4 & 12.5 & 21.9 & 0.0 & 0.0 & 1.6 & 0.0 & 0.0 \\
\hline $\mathrm{ph}$ & 0.6 & 0.0 & 0.0 & 1.9 & 3.8 & 0.0 & 1.3 & 0.0 & 0.0 & 18.8 & 36.3 & 1.3 & 32.5 & 0.6 & 0.0 & 0.6 & 1.3 & 1.3 \\
\hline s & 4.7 & 0.2 & 1.6 & 2.2 & 10.0 & 3.1 & 6.7 & 0.2 & 3.3 & 2.0 & 0.5 & 0.0 & 0.9 & 29.5 & 0.3 & 20.8 & 7.7 & 5.8 \\
\hline$s^{\prime}$ & 12.5 & 0.0 & 3.1 & 0.0 & 14.1 & 3.1 & 1.6 & 0.0 & 0.0 & 1.6 & 0.0 & 0.0 & 1.6 & 20.3 & 0.0 & 21.9 & 15.6 & 3.13 \\
\hline te & 5.2 & 0.4 & 0.7 & 2.6 & 9.4 & 2.6 & 5.2 & 0.2 & 1.9 & 1.6 & 0.5 & 0.0 & 0.5 & 26.0 & 0.4 & 28.5 & 12.9 & 1.4 \\
\hline tch & 7.8 & 0.0 & 0.0 & 3.1 & 8.6 & 7.8 & 0.0 & 0.0 & 0.8 & 0.0 & 1.6 & 0.0 & 0.0 & 28.9 & 0.0 & 29.7 & 10.2 & 0.78 \\
\hline Frequency & 27 & 6 & 4 & 9 & 34 & 21 & 17 & 4 & 3 & 13 & 11 & 2 & 5 & 20 & 2 & 18 & 4 & \\
\hline
\end{tabular}

Initial phoneme /r/, /t $\epsilon^{\prime} /$ were not used in the Korean Standard Monosyllabic Word List for Adults (KS-MWL-A).

'[] means zero consonant. 
균 정반응률은 $13.00 \%$ 였으며, 음소 정반응률의 평균과 표준편차 는 초성자음 $19.04 \% \pm 14.80 \%$, 중성모음 $48.26 \% \pm 17.91 \%$, 종성자 음 $44.77 \% \pm 15.40 \%$ 였다. 일원분산분석 결과, 초성, 중성, 종성 음 소 간 유의한 차이를 $\left(F_{(2,34)}=400.040, p=.000\right)$ 를 보였으며, 사후분 석 결과, 초성은 중성과 종성 간 유의한 차이 $(p=.000)$ 를 보였으나 중성과 종성에서는 유의한 차이가 없었다 $(p=.387)$.

\section{초성자음의 독화 정확도}

초성자음 16 개와 무초성 [ ] 1개의 독화 정확도 및 반응음소의 출 현율을 혼동 행렬로 나타낸 결과는 Table 1과 같다. /ㅂ/(60.80\%)을 제외하고는 모두 $40 \%$ 이하의 낮은 독화 정확도를 나타내었는데 $30 \%$ 대 /[ ]/(37.68\%), /프/(32.50\%), 20\%대/人/(29.53\%), / ㅈ/(28.47\%), /ㅁ/(25.24\%), / ᄀ/(23.96\%), /ㄷ/(20.22\%), 10\%대//(15.28\%), / 삐/ (12.50\%), / / /(10.16\%), 10\% 미만은 / E /(5.21\%), /TT/(3.65\%), /匹 / (2.08\%), /씨/(0\%) 순이었다. 초성자음 간 독화 정확도에 대한 일원 분산분석 결과, 유의미한 차이를 보였으며 $\left(F_{(7.891,244.633)}=30.695\right.$, $p=.000)$, 사후분석 결과, 자음 /비이 모든 자음에 비해 유의하게 높았고, 다음으로 /[ ], 프, ㅅ, ㅈ, ㅁ, ᄀ, ᄃㄱ군이 /E, ㄱ, 匹, ㅆ/군 에 비해 유의하게 높은 것으로 나타났다 $(p=.0029)$.

초성의 조음위치에 따른 독화 정확도의 평균과 표준편차는 양순 음(/ㅂ, 빠, 프, ㅁ/) $31.80 \% \pm 7.43 \%$ 로 가장 높았고, 경구개음(/ᄌ, ㅊ/) $19.14 \% \pm 11.13 \%$, 연구개음(/ᄀ, $\Pi, ~ ㄱ, ~ ㅇ /) ~ 18.20 \% \pm 6.47 \%$, 성문음(/ㅎ//) $18.05 \% \pm 12.85 \%$, 치경음(/ᄃ, 匹, ㅌ, ㅅ, ㅆ, ㄴ/) $11.05 \%$ $\pm 5.33 \%$ 순이였다(Figure 1). 초성의 조음위치에 따른 독화 수행도 의 차이를 확인하기 위해 일원분산분석을 실시한 결과, 유의미한 차이가 있는 것으로 나타났다 $\left(F_{(2.589,80.252)}=26.171, p=0.000\right)$. 사후 분석 결과, 양순음이 다른 음들에 비해 유의하게 높았고 $(p<.01)$, 치경음이 다른 음들에 비해 유의하게 낮았으나 $(p<.01)$ 경구개음, 연구개음, 성문음 사이에 유의미한 차이가 없었다 $(p<.01)$.

초성의 조음방법에 따른 평균 독화 정확도 및 표준편차는 비음

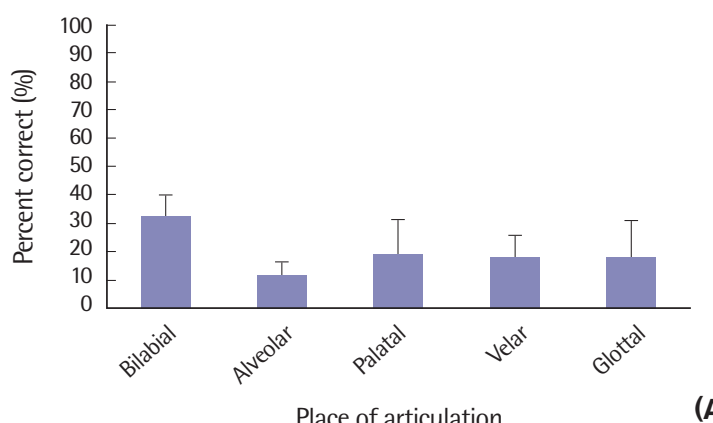

(A)
(/ロ, ᄂ, O/) 23.27\% $\pm 10.84 \%$, 파찰음(/ス, ᄎ/) $19.14 \% \pm 11.13 \%$,

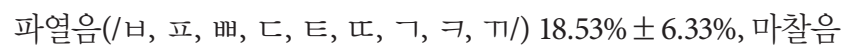
(/人, ㅆ, ㅎ/ $) 15.91 \% \pm 9.36 \%$ 순으로 일원분산분석 결과, 조음방법 간 유의미한차이가 나타나지 않았다 $\left(F_{(3,93)}=3.300, p>.01\right)$.

\section{중성모음의 독화 정확도}

중성모음별 독화 정확도 및 반응음소의 출현율을 혼동 행렬로 나타낸 결과는 Table 2 와 같다. $70 \%$ 이상의 독화 정확도를 보인 것은 단모음/ / /(84.38\%), / / /(74.46\%), / / /(93.64\%), / / /(88.19\%), / T/ (77.81\%), / 기/(92.71\%), 이중모음 / 사/(71.88\%)이었다. 50\%대의 정 확도를 보인 것은 단모음 / / / $(52.60 \%)$, 이중모음 /月/(58.75\%), 30\% 대의 정확도를 보인 것은 단모음 $/$ 기/(30.00\%), 이중모음 $/ \pi /(33.33 \%)$, $10 \%$ 대의 정확도를 보인 것은 단모음 / / / / $(10.94 \%), /$ / / $15.14 \%)$, 이 중모음 /교/(14.38\%), / / /(10.42\%), $10 \%$ 미만의 정확도를 보인 것은 이중모음/月/ /(7.29\%)이었다.

중성 음소 17 개의 독화 정확도에 대한 일원분산분석 결과, 유의 미한 차이가 있었으며 $\left(F_{(6.459,200.229)}=98.712 p=.000\right)$, 사후분석 결

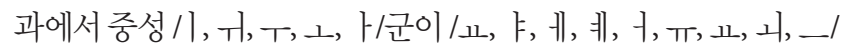
군에 비해 유의미하게 높은 것으로 나타났다 $(p=.0029)$.

중성모음을 단모음과 이중모음, 평순모음과 원순모음, 전설모음 과 후설모음으로 각각 나누어 독화 정확도의 평균과 표준편차를 살펴본 결과(Figure 2), 단모음(/ / , ㅐ, ㄱ, 게, 1, ㅅ, 기, , 기, _/) 은 $61.95 \% \pm 8.06 \%$, 이중모음(/k, ㅋ, 켸, 과, 표, $\pi,-1 /$ )은 $27.68 \%$ $\pm 10.62 \%$ 로 단모음이 이중모음에 비해 독화 정확도가 유의하게 높 았다 $(t=13.064, p=.000)$. 평순모음(/ / , H, , - . 게. I, _/ )은 $55.34 \%$ $\pm 7.96 \%$, 원순모음(/T, ㄴ, 기, 기/)은 $72.70 \% \pm 12.05 \%$ 로 원순모 음이 평순모음에 비해 독화 정확도가 유의하게 높았으며 $(t=-8.200$, $p=.000)$, 전설모음(/l, 기, 게, 기, ㅐ/)은 $56.36 \pm 11.07 \%$, 후설모음

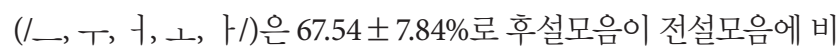
해 독화정확도가유의하게 높은 것으로 나타났다 $(t=-6.074, p=.000)$.

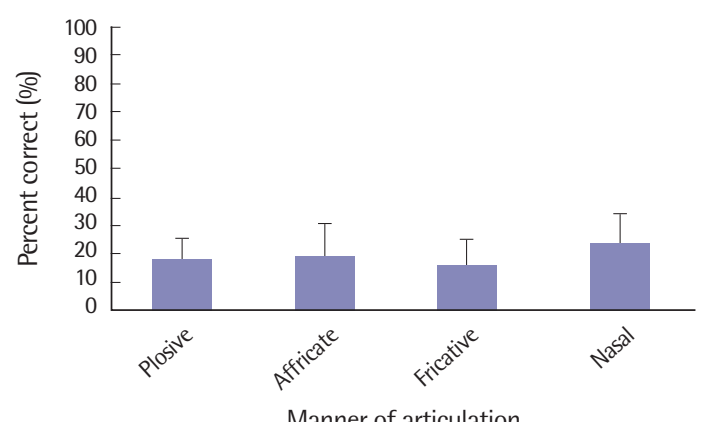

(B)

Figure 1. Speechreading accuracy of initial consonants according to (A) place of articulation and (B) manner of articulation. 
Table 2. Confusion matrix of medial phonemes (\%)

\begin{tabular}{|c|c|c|c|c|c|c|c|c|c|c|c|c|c|c|c|c|c|c|}
\hline \multirow{3}{*}{ Stimulus } & \multicolumn{18}{|c|}{ Reponse } \\
\hline & t & $H$ & $t$ & $\|$ & 1 & $\perp$ & $\perp$ & $T$ & $T$ & - & k & F & $\#$ & 나 & $\Perp$ & $\pi$ & -1 & 내 \\
\hline & a & $æ$ & $\Lambda$ & e & i & 0 & $\emptyset$ & u & wi & u & ja & $j \Lambda$ & $\mathrm{j} \varepsilon$ & wa & jo & ju & ui & $W \varepsilon$ \\
\hline a & 84.3 & 7.2 & 0.5 & 3.0 & 1.0 & 0.2 & 0.0 & 0.2 & 0.2 & 0.2 & 2.7 & 0.2 & 0.2 & 0.2 & 0.0 & 0.0 & 0.0 & 0.0 \\
\hline$æ$ & 16.9 & 52.6 & 1.0 & 17.0 & 4.4 & 0.0 & 0.8 & 0.0 & 0.3 & 0.0 & 1.6 & 0.0 & 4.2 & 0.0 & 0.3 & 0.0 & 0.0 & 0.8 \\
\hline$\Lambda$ & 1.1 & 0.1 & 74.4 & 0.0 & 0.8 & 1.5 & 0.0 & 0.0 & 0.2 & 0.0 & 0.0 & 20.6 & 0.0 & 0.0 & 0.3 & 0.0 & 0.0 & 0.1 \\
\hline e & 32.8 & 39.0 & 3.1 & 10.9 & 4.7 & 0.0 & 1.6 & 0.0 & 0.0 & 0.0 & 0.0 & 4.7 & 0.0 & 0.0 & 0.0 & 0.0 & 0.0 & 1.6 \\
\hline i & 1.0 & 0.6 & 0.8 & 0.2 & 93.6 & 0.0 & 0.0 & 0.0 & 1.0 & 1.3 & 0.0 & 0.2 & 0.2 & 0.0 & 0.0 & 0.0 & 0.5 & 0.0 \\
\hline 0 & 0.4 & 0.1 & 0.8 & 0.0 & 0.2 & 88.1 & 0.0 & 1.0 & 0.0 & 0.2 & 0.0 & 0.0 & 0.0 & 0.0 & 8.5 & 0.0 & 0.1 & 0.0 \\
\hline$\varnothing$ & 0.0 & 1.3 & 0.0 & 0.0 & 0.0 & 0.6 & 30.0 & 0.6 & 11.8 & 0.0 & 0.0 & 0.0 & 0.0 & 0.0 & 0.6 & 0.6 & 0.0 & 46.9 \\
\hline u & 0.5 & 0.2 & 0.2 & 0.0 & 0.0 & 2.8 & 0.0 & 77.8 & 1.3 & 0.6 & 0.0 & 0.2 & 0.0 & 0.0 & 0.2 & 16.2 & 0.0 & 0.0 \\
\hline wi & 0.0 & 0.0 & 0.0 & 0.0 & 4.2 & 0.0 & 0.0 & 0.0 & 92.7 & 0.0 & 0.0 & 0.0 & 0.0 & 0.0 & 0.0 & 0.0 & 1.0 & 0.0 \\
\hline $\mathrm{u}$ & 0.7 & 0.2 & 0.5 & 0.2 & 79.5 & 0.2 & 0.0 & 0.5 & 1.2 & 15.1 & 0.0 & 0.2 & 0.0 & 0.0 & 0.0 & 0.0 & 1.2 & 0.0 \\
\hline ja & 79.1 & 8.3 & 0.0 & 1.0 & 0.0 & 0.0 & 0.0 & 0.0 & 0.0 & 0.0 & 10.4 & 0.0 & 1.0 & 0.0 & 0.0 & 0.0 & 0.0 & 0.0 \\
\hline$j \Lambda$ & 0.3 & 0.6 & 37.1 & 0.3 & 0.6 & 0.3 & 0.0 & 0.6 & 0.0 & 0.0 & 0.3 & 58.7 & 0.0 & 0.0 & 0.0 & 0.0 & 0.0 & 0.0 \\
\hline je & 7.3 & 53.1 & 0.0 & 19.7 & 6.3 & 1.0 & 3.1 & 0.0 & 0.0 & 0.0 & 0.0 & 0.0 & 7.2 & 0.0 & 0.0 & 0.0 & 0.0 & 0.0 \\
\hline wa & 0.0 & 0.0 & 0.0 & 1.6 & 0.0 & 0.0 & 3.1 & 0.0 & 0.0 & 0.0 & 0.0 & 0.0 & 0.0 & 71.8 & 0.0 & 0.0 & 0.0 & 20.3 \\
\hline jo & 0.0 & 0.0 & 0.0 & 0.0 & 0.6 & 78.7 & 0.0 & 1.9 & 0.0 & 0.6 & 0.0 & 1.3 & 0.0 & 0.6 & 14.3 & 1.3 & 0.0 & 0.0 \\
\hline ju & 0.0 & 0.0 & 0.0 & 0.0 & 0.0 & 0.0 & 0.0 & 63.5 & 0.0 & 0.0 & 0.0 & 1.0 & 0.0 & 0.0 & 0.0 & 33.3 & 0.0 & 0.0 \\
\hline ui & 3.1 & 0.0 & 3.1 & 0.0 & 84.3 & 0.0 & 0.0 & 0.0 & 3.1 & 3.1 & 0.0 & 0.0 & 0.0 & 0.0 & 0.0 & 0.0 & 0.0 & 0.0 \\
\hline Frequency & 42 & 12 & 23 & 2 & 26 & 27 & 5 & 20 & 3 & 13 & 3 & 10 & 3 & 2 & 5 & 3 & 1 & \\
\hline
\end{tabular}

Medial phoneme /ye/, /we/, /Ws/, /we/ were not used in the Korean Standard Monosyllabic Word List for Adults (KS-MWL-A).
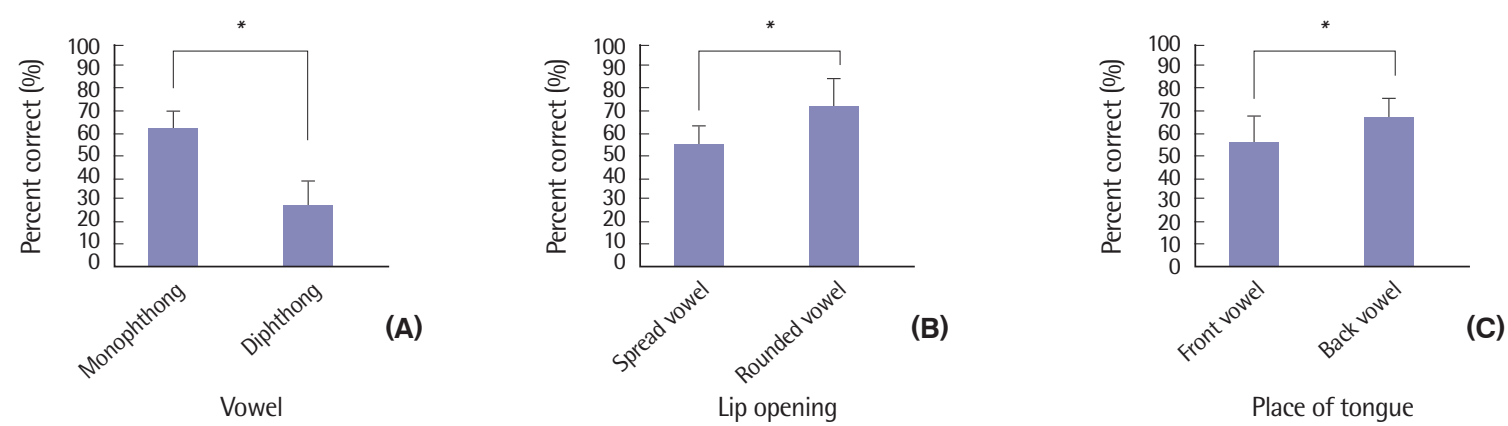

Figure 2. Speechreading accuracy of medial vowels according to $(A)$ monophthong vs. diphthong, (B) spread vowel vs. rounded vowel, and (C) front vowel vs. back vowel.

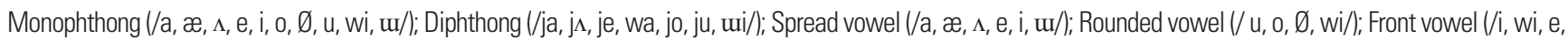
$\emptyset, æ /)$; Back vowel $(/ \mathrm{u}, \mathrm{u}, \Lambda, 0, \mathrm{a} /){ }^{*} p<.001$.

\section{종성자음의 독화 정확도}

한국어의 7종성법에 따른 종성자음별 독화 정확도 및 반응음소 의 출현율을 혼동 행렬로 나타낸 결과는 Table 3과 같다. /ㄴ/, /리 은 $70 \%$ 대의 정확도를, [ ],/ㅁ/,/ㅂ/은 50\%대의 정확도를 보였다. 종 성자음 $/ 0 /$ 의 독화 정확도는 $20 \%$ 대였으며, /ㄷ/은 $10 \%$ 대, / ㄱ/은 $10 \%$ 미만으로 나타났다. 종성 음소 8 개의 정반응률에 대한 일원분 산분석 결과로 유의미한 차이가 있었으며 $\left(F_{(2.653,45.101)}=34.795\right.$, $p=.000)$, 사후분석 결과에서 종성 /ㄹ, ᄂ, [ ]/군이/ ᄃ, O, ᄀᄀ/군에 비해 유의하게 높은 정확도를 보였다 $(p=.006)$.
종성 음소를 조음위치에 따라 나누었을 때, 평균 정반응률이 양 순음(/, ㅂ/ /) $54.17 \% \pm 7.20 \%$, 치경음(/ᄂ, ᄃ, ㄹ/) $54.01 \% \pm 8.55 \%$, 연구개음(/ᄀ, ㅇ/ / $13.65 \% \pm 8.54 \%$ 의 순으로 나타났으며(Figure 3),

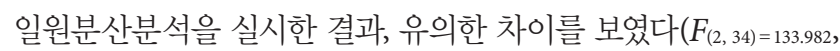
$p=.000)$. 사후분석 결과, 연구개음이 다른 음들에 비해 유의하게 낮은 정확도를 보였다 $(p<.001)$.

\section{초성 - 중성 · 종성의 독화소군 분석}

한국어 단음절어 200 개에 대한 독화 검사 결과에서 초성, 중성, 
Table 3. Confusion matrix of final phonemes (\%)

\begin{tabular}{|c|c|c|c|c|c|c|c|c|}
\hline \multirow{3}{*}{ Stimulus } & \multicolumn{8}{|c|}{ Response } \\
\hline & \multirow{2}{*}[]{$^{\dagger}$} & \multirow{2}{*}{$\begin{array}{l}\text { ᄀ } \\
\mathrm{k}\end{array}$} & \multirow{2}{*}{$\begin{array}{l}\text { ᄂ } \\
\mathrm{n}\end{array}$} & \multirow{2}{*}{$\begin{array}{l}\text { c } \\
\text { d }\end{array}$} & \multirow{2}{*}{$\begin{array}{l}e \\
r\end{array}$} & \multirow{2}{*}{$\begin{array}{l}\square \\
\mathrm{m}\end{array}$} & \multirow{2}{*}{$\begin{array}{l}\forall \\
p\end{array}$} & \multirow{2}{*}{$\begin{array}{l}0 \\
y\end{array}$} \\
\hline & & & & & & & & \\
\hline [] & 59.88 & 3.14 & 5.31 & 0.30 & 21.63 & 1.05 & 0.52 & 8.16 \\
\hline k & 31.45 & 8.06 & 11.69 & 1.61 & 35.89 & 0.00 & 0.40 & 10.89 \\
\hline$n$ & 9.71 & 2.00 & 70.00 & 1.71 & 12.29 & 1.43 & 0.57 & 2.29 \\
\hline d & 6.49 & 0.54 & 56.22 & 17.84 & 7.03 & 2.70 & 2.16 & 7.03 \\
\hline$r$ & 13.10 & 0.58 & 8.29 & 0.58 & 71.87 & 1.16 & 1.16 & 3.28 \\
\hline $\mathrm{m}$ & 1.31 & 0.26 & 0.26 & 0.00 & 0.26 & 54.45 & 43.19 & 0.26 \\
\hline$p$ & 0.00 & 0.00 & 1.11 & 0.00 & 0.00 & 43.65 & 53.04 & 2.21 \\
\hline$\eta$ & 32.40 & 1.56 & 7.79 & 0.62 & 33.96 & 2.49 & 0.94 & 20.25 \\
\hline Frequency & 75 & 14 & 20 & 11 & 29 & 22 & 11 & 18 \\
\hline
\end{tabular}

†[ ] means zero consonant.

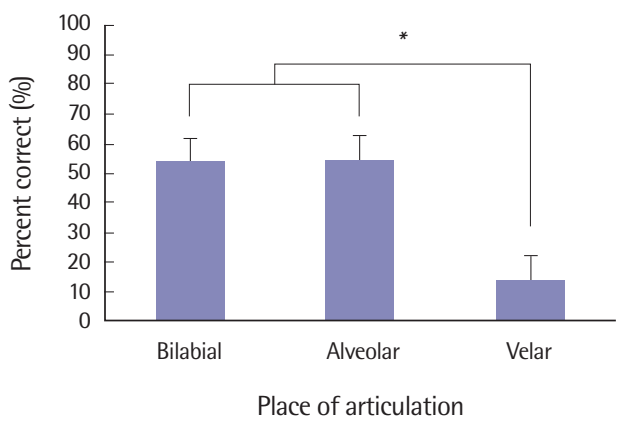

Figure 3. Speechreading accuracy of final consonants according to place of articulation.

${ }^{*} p<.01$.

종성 음소별로 음소 정반응률과 오류음소 출현율을 분석하여 반 응음소군을 결정하였으며, 반응음소군이 중첩되는 음소끼리 분류 하고 누적 반응률 $60 \%$ 이상을 기준으로 독화소군을 결정하였다.

\section{초성자음의 독화소군}

초성자음별로 동일 반응음소군을 보이는 초성끼리 분류하여 누 적 반응률 $60 \%$ 이상을 기준으로 독화소를 결정한 결과는 Table 4

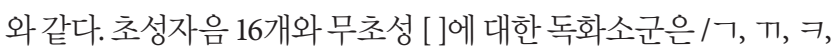

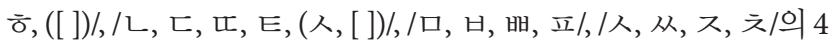
개로 분류하였다. 초성자음 $/ \neg, \pi, \exists$, ㅎ/을 사용한 자극을 제시 했을 때, 반응음소군 /ᄀ, ㅎ/의 평균 출현율은 $29.31 \%$ 로 나타났으 며, 반응음소 /[ ]/이 포함될 때 총 출현율이 60.78\%로 증가하였다. 이에 /[ ]/을 반응음소로 포함하여 / ᄀ, ד, ᄀ, ㅎ, ([ ])/을 하나의 독 화소군으로 결정했을 때 누적 정반응률 $65.51 \%$ 로 기준을 충족하 였다. 초성자음/ㄴ, ᄃ, ㄸ, 티을 사용한 자극을 제시했을 때, /ㄴ, ㄷ/의 평균 출현율은 $21.52 \%$ 였으며 반응음소/시과/[ ]/이 포함될
Table 4. The response phoneme clusters, frequency and the viseme clusters on the initial phoneme

\begin{tabular}{|c|c|c|c|}
\hline Stimulus & Response & $\begin{array}{c}\text { Frequency } \\
(\%)\end{array}$ & $\begin{array}{l}\text { Viseme cluster } \\
\text { (percent correct) }\end{array}$ \\
\hline$/ k, k^{\prime}, \mathrm{kh}, \mathrm{h} /$ & $/ k, h,[]^{\dagger} /$ & 60.78 & $/ k, k^{\prime}, k h, h,\left([]^{\circ} /(65.51)\right.$ \\
\hline /k/ & /k, h, [ ]/ & 61.36 & \\
\hline$/ k^{\prime} /$ & $/ k,[] /$ & 46.36 & \\
\hline /kh/ & $/ k_{,}[] /$ & 64.85 & \\
\hline /h/ & $/ k, h,[] /$ & 57.29 & \\
\hline /n, d, t', th/ & $/ s, n, d /$ & 38.23 & $/ \mathrm{n}, \mathrm{d}, \mathrm{t}^{\prime}$, th, $(\mathrm{s},[]) /(61.65)$ \\
\hline /n/ & $/ s, n, d /$ & 46.72 & \\
\hline$/ d /$ & $/ s, n, d /$ & 42.65 & \\
\hline$/ t^{\prime} /$ & $/ s, d,[] /$ & 30.74 & \\
\hline /th/ & /s, n, d, [ ]/ & 56.25 & \\
\hline$/ m, p, p^{\prime}, p h /$ & /m, p, ph/ & 87.41 & $/ m, p, p^{\prime}, p h /(91.93)$ \\
\hline$/ \mathrm{m} /$ & /m, p/ & 66.83 & \\
\hline$/ \mathrm{p} /$ & $/ \mathrm{m}, \mathrm{p} /$ & 78.70 & \\
\hline$/ p^{\prime} /$ & /p, ph/ & 70.32 & \\
\hline /ph/ & /p, ph/ & 68.75 & \\
\hline /s, s', tc, tch/ & /s, tc, tch/ & 62.98 & $/ s^{\prime}, s^{\prime}, t c, t c h /(63.14)$ \\
\hline /s/ & $/ s, t_{\varphi},[] /$ & 60.31 & \\
\hline$/ s^{\prime} /$ & $/ s, t c, t c h, h /$ & 71.88 & \\
\hline$/ \mathrm{tc}_{\mathrm{c}} /$ & /s, tc, tch/ & 67.36 & \\
\hline /tch/ & /s, tc, tch/ & 68.76 & \\
\hline
\end{tabular}

( ) means Including into the viseme cluster as a response phoneme. t[ ] means zero consonant.

때 총 $53.09 \%$ 로 증가하였다. 이에 /ㅅ, [ ]/을 반응음소로 포함하여 / ᄂ, ᄃ, ᄄ, E, (ㅅ, [ ] ])/를 하나의 독화소군으로 결정했을 때, 누적 정반응률 $61.65 \%$ 로 기준을 충족하였다. 초성자음 /ㅁ, ㅂ, 빠, 프/ 을 사용한 자극을 제시했을 때 반응음소군 /ㅁ, ㅂ, 프/의 평균 빈 도율은 $87.41 \%$ 였으며, /ㅁ, ㅂ, 빠, 프/를 하나의 독화소군으로 결정 했을 때 정답율 $91.93 \%$ 로 기준을 충족하였다. 초성자음/ㅅ, 씨, 즈, 치을 사용한 자극을 제시했을 때 반응자음군 / ㅅ, 즈, 치의 평균 빈도율은 $62.98 \%$ 이었으며, / ㅅ, 씨, ㅈ, 치을 하나의 독화소군으로 결정했을 때 정답율 $63.14 \%$ 로 기준을 충족하였다.

\section{중성모음의 독화소군}

중성모음별로 반응음소군이 중첩되는 음소끼리 분류하여 누적 반응률 $60 \%$ 이상을 기준으로 독화소를 결정한 결과는 Table 5 와

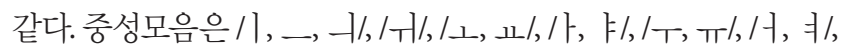
/과, 기, (개)/,//月, ㅐ, 게/ 8개군으로 분류되었다. 예를 들어. 중성모 음 /과, 니/를 제시한 경우, 반응음소/놔, 니/의 출현율이 $52.51 \%$, /개/의 출현율이 $33.60 \%$ 로 나타남에 따라/개/를 반응음소로 포함 하고 /과, 기, (개)/를 하나의 독화소군으로 결정했을 때, 정답률이 
Table 5. The response phoneme clusters, frequency and the viseme clusters on the medial phoneme

\begin{tabular}{|c|c|c|c|}
\hline Stimulus & Response & Frequency (\%) & Viseme cluster (\%) \\
\hline /i, u, wi// & /i/ & 85.86 & /i, w, wi/(92.95) \\
\hline /i/ & /i/ & 93.63 & \\
\hline /w/ & /i/ & 79.57 & \\
\hline /uil/ & /i/ & 84.38 & \\
\hline /wi/ & /wi/ & 92.71 & /wi/(92.71) \\
\hline /o, jo/ & /0/ & 83.47 & /o, jo/(94.89) \\
\hline /0/ & /0/ & 88.19 & \\
\hline /jo/ & /0/ & 78.75 & \\
\hline /a, ja/ & /a/ & 81.78 & /a, ja/(88.33) \\
\hline /a/ & /a/ & 84.38 & \\
\hline /ja/ & la/ & 79.71 & \\
\hline /u, ju/ & $/ \mathrm{u} /$ & 70.68 & /u, ju/(95.47) \\
\hline /u/ & /u/ & 77.81 & \\
\hline /ju/ & /u/ & 63.54 & \\
\hline$/ \Lambda, j \Lambda /$ & $/ \Lambda /$ & 55.83 & $/ \Lambda, j \Lambda /(95.53)$ \\
\hline$|\Lambda|$ & $/ \Lambda /$ & 74.46 & \\
\hline /jN/ & /jN/ & 58.75 & \\
\hline /wa, Ø/ & /wa, Ø, we/ & 86.10 & /wa, Ø, $(w \varepsilon)^{\circ} /(86.10)$ \\
\hline /wa/ & /wa, we/ & 92.19 & \\
\hline $10 /$ & $/ \emptyset, w \varepsilon /$ & 76.88 & \\
\hline$/ \mathrm{j} \varepsilon, æ, \mathrm{e} /$ & /æ, e/ & 64.15 & $/ j \varepsilon, æ, e /(67.97)$ \\
\hline /je/ & /æ, e/ & 72.92 & \\
\hline /æ/ & $/ æ, e, a /$ & 86.46 & \\
\hline le/ & |æ, a/ & 71.87 & \\
\hline
\end{tabular}

o) means Including into the viseme cluster as a response phoneme.

$86.10 \%$ 로 증가하였다.

\section{종성자음의 독화소군}

종성 위치에 올 수 있는 자음( ᄀ, ᄂ, ᄃ, ㄹ, ㅁ, ㅂ, 이별로 반응 음소군이 중첩되는 것끼리 분류하여 반응률 $60 \%$ 이상을 기준으 로 독화소를 결정한 결과는 Table 6과 같다. 종성자음은 [ ], / ᄀ, ㅇ/, /ㄴ, ㄷ/,/ㄹ/,/ㅁ, 비 5개군으로 분류하였다. 종성자음/ᄀᄀ, ㅇ/군에 서 무종성([ ])의 평균 출현율이 $31.93 \%$ 로 나타남에 따라 무종성을 일종의 반응음소로 간주하여 독화소군에 포함하였다. [ ]을 포함 함에도 불구하고 반응음소의 전체 반응률은 $52.31 \%$ 로 $60 \%$ 에 미 치지 못하였다.

\section{중성모음별 초성 독화소군 정반응률}

초성 독화소군이 각 중성모음과 결합했을 때의 정반응률은 Table 7과 같다. 초성 독화소/ㅁ, ㅂ, 뼈, 프/군은 96.88\% (/十, ㅋ//)-78.13\% (/ㅆ//)로 가장 높은 점수를 보였으며,/ᄀ, ㄲ, ㅋ, ㅎ, ([])/군은 93.75\% (/가/)-28.57\% (/교/)로 모음에 따라 가장 큰 점수범위를 보였다. /ㄴ,
Table 6. The response phoneme clusters, frequency and the viseme clusters on the final phoneme

\begin{tabular}{lccc}
\hline Stimulus & Response & Frequency (\%) & Viseme cluster (\%) \\
\hline[]$^{\dagger}$ & {[]} & 59.88 & {[]$(59.88)$} \\
$/ \mathrm{k}, \mathrm{y} /$ & $/[], \mathrm{k}, \mathrm{y} /$ & 52.31 & $/ \mathrm{k}, \mathrm{y},\left([\mathrm{]})^{\circ} /(52.31)\right.$ \\
$/ \mathrm{k} /$ & $/[\mathrm{]}, \mathrm{k}, \mathrm{y} /$ & 50.4 & \\
$/ \mathrm{y} /$ & $/[\mathrm{]}, \mathrm{y} /$ & 52.65 & \\
$/ \mathrm{n}, \mathrm{d} /$ & $/ \mathrm{n}, \mathrm{d} /$ & 72.89 & $/ \mathrm{n}, \mathrm{d} /(72.89)$ \\
$/ \mathrm{n} /$ & $/ \mathrm{n} /$ & 70.00 & \\
$/ \mathrm{d} /$ & $/ \mathrm{n}, \mathrm{d} /$ & 74.06 & \\
$/ \mathrm{r} /$ & $/ \mathrm{r} /$ & 71.87 & $/ \mathrm{r} /(71.87)$ \\
$/ \mathrm{m}, \mathrm{p} /$ & $/ \mathrm{m}, \mathrm{p} /$ & 97.17 & $/ \mathrm{m}, \mathrm{p} /(97.17)$ \\
$/ \mathrm{m} /$ & $/ \mathrm{m}, \mathrm{p} /$ & 97.64 & \\
$/ \mathrm{p} /$ & $/ \mathrm{m}, \mathrm{p} /$ & 96.69 & \\
\hline
\end{tabular}

() ) means Including into the viseme cluster as a response phoneme. †[ ] means zero consonant.

Table 7. The percent correct scores of viseme cluster on the initial consonants following vowels (\%)

\begin{tabular}{lcccc}
\hline \multirow{4}{*}{ Vowel } & \multicolumn{4}{c}{ Viseme cluster } \\
\cline { 2 - 5 } & /k, kh, k', h, [ ]/ & /n, d, t', th, (s), []/ & /m, p, ph, p'/ & /s, s', tc, tch/ \\
\hline /a/ & 78.05 & 70.00 & 95.00 & 72.41 \\
/æ/ & 48.42 & 68.75 & 89.06 & 53.68 \\
/ $/$ & 87.30 & 66.82 & 98.44 & 67.97 \\
/e/ & - & 75.00 & - & - \\
/i/ & 69.47 & 60.94 & 92.13 & 68.99 \\
/0/ & 75.63 & 73.61 & 85.83 & 54.17 \\
/Ø/ & 76.56 & 75.00 & - & 53.13 \\
/u/ & 42.75 & 57.81 & 96.88 & 54.38 \\
/wi/ & 84.38 & - & - & 37.50 \\
/w/ & 41.05 & 49.33 & - & - \\
/ja/ & - & - & - & - \\
/js/ & 65.08 & - & 94.49 & - \\
/je/ & 62.50 & - & 96.88 & - \\
/wa/ & 93.75 & - & - & - \\
/jo/ & 28.57 & - & 78.13 & - \\
/ju/ & 43.75 & - & - & - \\
/wui/ & - & - & - & - \\
\hline
\end{tabular}

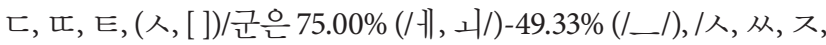
ㅊ/군은 $72.41 \%(/ / /)-37.50 \%(/ /$ T//)의 점수 범위를 나타내었다.

\section{논의 및 결론}

오늘날 보청기나 인공와우를 착용한 청각장애인들의 듣기 능력 이 전반적으로 향상되었음에도 의사소통에서 시각적인 정보를 활 용하는 능력은 여전히 중요한 부분을 차지한다(Park et al., 2016). 
제한된 청각적 정보를 경험하는 청각장애인은 화자의 얼굴을 관찰 함으로써 발화 내용을 이해하는 과정, 즉 독화를 통해 의사소통의 한계를 보완할 수 있다. 그러므로 청각장애인이 시각적 정보를 활 용하여 의사소통을 극대화할 수 있도록 독화소 체계에 바탕을 둔 효율적인 독화 방법과 전략들을 모색할 필요가 있다. 기존의 한국 어 독화소 체계에 관한 연구들은 한국어 음운론적 체계에 가시적 요소들을 결합하여 독화소 체계를 분류하였다(Kim, 1992; Lee et al., 2006). 실제로 독화 능력을 측정한 연구에서는 특정 자모음 환 경에서만 측정하였으므로 $(\mathrm{Kim}, 1993,1997)$ 다양한 자모음 환경에 서의 의사소통 능력을 반영할 필요성이 있다. 그러므로 본 연구에 서는 일상회화체에서 자주 사용되는 음소를 중심으로 다양한 자 모음 환경에서 독화 정확도를 확인하고, 초성, 중성, 종성별 혼동행 렬을 정리하여 군집 내 누적 정반응률 $60 \%$ 를 기준으로 음소별 독 화소군을 살펴보고자 하였다.

본 연구에서는 일상회화체의 빈도, 음소의 균형, 친숙성 등을 고 려하여 개발된 어표로써 초성은 /르, 찌이 제외된 초성자음 16 개 와 무초성 [ ] 1개 포함 총 17개, 중성모음은/月/, / 내/,/T//,/T//가 제 외된 17 개, 종성은 종성자음 7 개와 무종성 [ ] 포함 총 8 개로 구성되 어 있는 단음절어표를 사용하였다. 본 연구에서 무초성 및 무종성 형태를 독화소군에 포함시킨 것은 일상회화체에서 무초성 음절이 초성의 $15 \%$ (Byun, 2001)를 차지하고 있으며, 무종성 음절은 54\% (Park et al., 2007), 65\% (Byun, 2001), 68.91\% (Park, 1999) 등에 달 하는 것으로 보고된 것에 기반을 두고 있다. 특히 한국표준 단음절 어표에서 무종성 단어는 75 개로 $37.5 \%$ 의 비중을 차지하고 있으며, 본 연구결과에서 음소 정반응률이 $59.88 \%$ 인 것으로 나타난 가운 데 종성이 있는 자극을 제시했을 때 연구대상자의 $86.51 \%$ 가 종성 이 있는 것으로 반응하였다. 이러한 결과들은 한국어가 가지는 음 절 구조로 인해 연구대상자들이 종성의 유무에 민감하게 반응했 음을 시사한다.

본 연구결과에서 시각적 단서만 제공하고 독화검사를 실시하였 을 때, 한국표준 단음절어표는 단어 정반응률에서 목록 간 차이가 없었으며 $(p>.05)$, 전체 $13.00 \%$ 로 매우 저조하였다. 음소 정반응률 은 초성 $19.04 \%$, 중성 $48.26 \%$, 종성 $44.77 \%$ 로 초성자음의 제한된 시각적 특징이 독화 능력에 유의한 영향을 미치는 것으로 나타났 다. Kim (1997)은 음소 독화검사를 실시하여 독화에 변별적 단서로 작용할 수 있는 음소의 조음운동에 의한 시각적 특징의 제한성을 언급하며, 독화 지도 시 독화소 단위 간의 변별을 고려한 후에 독화 소 단위 내의 변별을 위해 청각 단서와 맥락 단서 등을 활용해야 함 을 강조하였다. 본 연구의 독화 수행력은 Lee (2010)의 연구에서의 초성 $20.83 \%$, 중성 $55.88 \%$, 종성 $50.00 \%$ 로 나타난 것과 대략적으
로 일치하였으나 Lee (2010)의 연구에서는 이중모음의 독화 정확도 가 $63.75 \%$ 로 나타난 반면, 본 연구에서는 $28.20 \%$ 로 나타났다. Lee (2010)의 연구에서는 모음 독화 과제 시 개구도의 변화를 최소화할 수 있는 $/ \mathrm{h} / \mathrm{V}-/ \mathrm{g} /$ 의 형태로 제시하였으나, 본 연구에서는 다양한 초 성과 종성을 결합하여 제시한 데 따른 결과로 설명할 수 있을 것이 다. 초성의 경우, 조음위치에서 가시성이 높은 양순음이 경구개, 연 구개, 성문음 및 치경음보다 유의하게 높은 점수를 보였으나 조음 방법 간에는 유의미한 차이가 없었다. $\operatorname{Kim}$ (1993)은 자음의 독화에 서 발생하는 혼동이 조음방법이 동일한 음소들보다는 조음위치가 동일한 음소들 사이에 더 많이 발생하였음을 보고하였으며, 이는 조음 시 나타나는 시각적 특징이 더 큰 유사성을 보이기 때문일 것 으로 보았다.

영어권에서 독화소를 결정하는 최소 기준을 주로 $70 \%$ 이상으로 설정하였는데 이는 연구자마다 임의적으로 정한 것으로서, Kim (1997)의 연구에서는 음소의 평균 독화 정확도를 기반으로 $60 \%$ 로 설정하여 한국어 독화소 체계를 분류하였다. 본 연구에서도 음소 별 평균 독화 정확도를 기반으로 살펴본 결과, 초성자음의 경우 대 부분의 후행모음별 반응음소군에서 유의미한 출현율을 보이는 음 소 수가 제한되었으므로 군집 내 누적 정반응률 $60 \%$ 를 기준으로 설정하였다. 초성은 이러한 설정 기준에 따른 독화소 체계의 분류 가 독화소 체계(Kim, 1992)와 초성과 종성자음 분류에서 거의 동 일하였으므로 타당한 것으로 여겨진다. 또한 모음의 경우, 대부분 의 독화소군에서 기준인 $60 \%$ 보다 훨씬 높은 $86 \%-95.93 \%$ 의 누적 반응률을 보이는 것으로 나타났지만 /月, ㅐ, 게/군의 $67.97 \%$ 를 고 려해 볼 때, $60 \%$ 기준은 적절한 최소 결정 기준이라고 판단된다. 단 종성자음의/ᄀ, 이의 경우 반응음소인 무종성 /[ ]/을 포함했을 때 에도 $52.31 \%$ 로 $60 \%$ 에 미치지 못하였다.

한국표준 단음절어표를 기반으로 다양한 자모음 환경하에서 초 성, 중성, 종성 음소에 대한 독화소군을 살펴본 결과, 초성은 / ᄀ

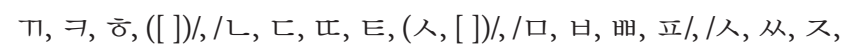

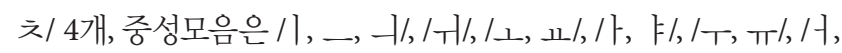
ㅋ//,/과, 니, (개)/,/月, ㅐ, 게/ 8개, 종성자음은 [ ],/ᄀ, O, ([ ])/,/L, ᄃᄃ/,/ㄹ/,/ㅁ, 비 5개로 분류하였다. 무초성 [ ]은 반응음소로 독화 소군/ᄀ, ㄱ, ㄱ, ㅎ/군과/ㄴ, ᄃ, , E/군에 포함하였으며, / 시은 반응음소로/L, ᄃ, , E/군 모두에 포함하였다. 반응음소/시이 / ᄂ, ㄷ/과 함께 동일 독화소군을 구성하는 것은 영어권에서의 독 화소 체계와 일치하며(Erber, 1974; Leaner, Sandridge, \& Kricos, 1987), 동일 독화소군에 반응음소 /[ ]/도 포함된 것은 Auer와 Bernstein (1997)의 연구에서 독화소군 수가 10 개 이하일 때의 독화소 체계와 일치한다. 또한 / 시 / 음소가 두 개의 독화소군에 포함된 경 
우는 방향성의 개념으로 설명할 수 있다. 방향성은 Fisher (1968)가 $/ \mathrm{n} /$ 자극에 대한 반응음소/t/의 출현율이 높았으나/t/에 대한/n/의 출현율은 낮았음을 보고한 것과 같은 맥락으로, 본 연구에서 특정 독화소군/ㄴ, ᄃ, ㄸ, E/에 대한/시의 반응음소 출현율이 높아그 독화소군에/시이 포함되지만/시의 반응음소로/ㄴ, ᄃ, ㄸ, E/의 출현율이 거의 없어 어떠한 음소도 / ㅅ, 씨, ㅈ, ㅊ/ 독화소군에 속 할 수 없었음을 의미한다.

본 연구에서 제시하는 독화소 체계를 한국어 독화소 체계에 대 한 선행연구들(Kim JH, 1992; Kim YW, 1993, 1997; Lee \& Kim, 1991; Lee et al., 2006)과 비교했을 때, 초성 및 종성자음의 독화소 는 Kim (1992)의 체계와, 중성모음의 독화소는 Kim (1997)의 체계 와 유사한 것으로 나타났다. 초성자음의 경우, $\operatorname{Kim}$ (1992)은 음운 론적 기초에 시각적 요소를 바탕으로 독화소를 4 개로 분류하였으 며, $\operatorname{Kim}(1997)$ 은 초성자음을 /a/와 결합시켜 독화능력을 실제로 측정하여 6 개로 나누었다. 초성자음에 / / / 와 / i/를 결합하여 제시하 였을 때 독화소 체계의 변동을 보고한 것(Kim, 1993)처럼 본 연구 에서는 다양한 모음환경에서 초성자음에 대한 독화 능력을 측정 한 결과로 초성자음에 /a/를 결합시킨 결과보다는 단음절어표에 포 함되지 않았던 /르, ㅉㄱㄱㅘ 포함된 /[ ]/초성을 제외하면 Kim (1992) 체계와 동일하게 4 개로 분류되었다. 종성자음의 경우도 Kim (1992) 의 분류와 거의 유사한 결과를 나타내었는데, 본 연구의 종성자음 독화소 체계는 종성자음 /리이 단독으로 독화소군을 구성한다는 점에서 / ᄂ, ㄷ/과 동일군에 포함시킨 Kim (1992)의 체계와 차이가 있었으나, Lee 등(2006)의 체계와는 일치하는 것으로 나타났다. 그 러므로 다양한 모음 환경에서 자음의 독화소 체계는 한국어 음운 론적 기초에 기반을 두며 가시적인 시각적 요소를 반영하고 있음 을 시사한다. 초성의 경우 후행하는 모음에 따라 정반응률과 반응 음소에서 영향을 받는 것으로 나타났으므로 이에 기반하여 검사 문항 및 훈련 위계를 정립하는 것이 효율적이라고 여겨진다.

본 연구에서 제시한 초성자음의 독화소 체계가 실제로 독화 능 력을 측정한 Kim (1997)의 연구와 차이를 보이는 이유로 첫째, 일 상회화체를 반영한 한국표준 단음절어표를 사용함으로써 다양한 중성모음과 종성자음으로 구성된 자극을 제시한 점을 들 수 있다. 둘째, 독화소가 가지는 방향성을 반영한 것으로서 특정 음소들을 반응음소로서 독화소군에 포함시킨 점을 들 수 있다. 셋째로 본 연 구를 위한 영상자료를 촬영할 때 두 명의 화자가 평상시와 같은 속 도로 발화한 결과로 독화 난이도가 상승하면서 반응음소군의 스 펙트럼이 넓어졌을 수 있다. 넷째로 본 연구에 참여한 연구대상자 들이 사전에 훈련을 받지 않았다는 점을 들 수 있으며, 자극을 다시 제시하지 않았고, 자극에 대한 반응시간도 5 초 이내로 제한함으로
써 독화 난이도가 상승하여 반응음소군에 영향을 미쳤을 수 있다.

중성모음 독화소의 경우, $\operatorname{Kim}$ (1992)과 $\operatorname{Kim}(1997)$ 의 연구에서 21 개 모음을 사용하였는데, 본 연구의 중성모음 독화소 체계는 반응 음소군 및 독화소군을 결정하지 못한/ㄱ//를 제외하면 Kim (1997) 의 9 개 독화소군 체계와 대부분 일치하여 나타나므로 음운론에 기 초한 Kim (1992)의 5 개 독화소군에 비해 실질적으로 독화를 실시 하였을 경우, 더 세분화된 변별력을 보이는 것으로 나타났다. 그러 므로 독화검사나 훈련을 위한 과제를 제시하는 경우, $\operatorname{Kim}(1992)$ 의

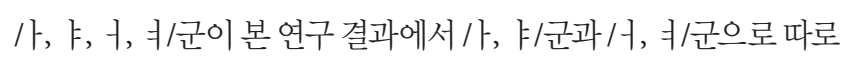
구분된 것처럼, 세분화된 항목으로 제시될 필요가 있음을 시사한다.

영어의 독화소 체계에서 후행모음이 자음의 독화소 체계에 영향 을 미친다는 것이 여러 학자들에 의해 보고되었다(Auer \& Bernstein, 1997; Owens \& Blazek, 1985). 한국어 독화소 체계에서도 Kim (1997) 은 한 음소를 어떤 모음의 맥락 속에 제시하느냐에 따라 시각 단서 가 다르게 나타날 수 있다고 하였고, Lee (2010)는 모음환경의 변화 에 따라 독화 정확도에 차이를 보이는 음소의 존재를 보고하면서 모음을 제한한 채 독화 수행도를 평가하는 것에 한계가 있을 수 있 음을 시사하였다. 초성 독화 과제에서의 평균 정확도는 모음 1 개 (//F/)를 사용했을 때 $38.3 \%$ (Kim, 1997), 모음 7개(/F, - , , , T, -, I, - //)를 사용했을 때 $20.83 \%$ (Lee, 2010), 모음 17 개를 사용한 본 연구결과에서 $19.04 \%$ 로, 모음 수의 증가에 따라 낮아지는 경향 을 보였다. 이러한 경향은 모음이 독화 과제의 난이도에 영향을 미 침을 보여준다. 특히 / / / 와 같이 개구도가 높은 모음과 결합할 때 초성 독화소군의 정반응률이 높게 나타났다(Table 7).

영어 독화소 체계에서는 자음과 결합하는 모음이 $/ \mathrm{u} /$ 일 때 독화 난이도가 상승하는 것으로 보고되고 있다(Auer \& Bernstein, 1997; Owens \& Blazek, 1985; Lesner \& Kricos, 1981; Wozniak \& Jackson, 1979). Owens와 Blazek (1985)은 /u/를 사용하여 자극을 제시했을 때 가시성이 가장 큰 독화소군인 $/ \mathrm{p}, \mathrm{b}, \mathrm{m} /$ 과 /f, $\mathrm{v} /$ 두 가지만 구별이 가능했음을 보고하였다. /f, v/는 한국어에 없는 음소이므로 본 연 구결과에서 /p, b, m/군에 대응하는 /ㅁ, ㅂ, 빠, 프/군이 모음/T/ 와 결합했을 때 정반응률이 $96.88 \%$ 로 나타났으나, 다른 독화소군 들이 모음 / T/와 결합했을 때 $42.75 \%$ (/ᄀ, T], ㄱ, ㅎ, ([ ])/-57.81\% (/ ᄂ, ᄃ, 匹, E, (人, [ ])/)로 정반응률이 크게 하락하는 것으로 나 타났다(Table 7). 이러한 결과는 영어의 독화소 체계에 대한 연구 결과들과 일치한다.

종성자음의 독화 정확도 역시 중성모음에 영향을 받는 것으로 나타났다. 독화소/ᄀᄀ, O, ([ ])/군은 선행모음이/—/일 경우를 제외 했을 때 평균 독화 정확도가 $63.22 \%$ 였으나, / _ / 와 결합했을 때 독 화 정확도가 $27.78 \%$ 로 크게 떨어지는 결과가 나타났다. 가장 높은 
평균 출현율을 보인 오류 반응음소는 /ㄹ/(72.22\%)이었으며, 이때 제시된 단어는 “능’이었다. 종성 / $/$ /은 가시성이 낮음에도 불구하고 연구대상자는 종성의 유무에 민감하게 반응하여 /리로 응답했을 가능성이 있다.

본 연구에서는 일상회화체의 다양한 자모음 상황에서 독화 수행 력을 살펴보았으며, 초성, 중성, 종성의 독화소 체계를 분석하였다. 한국표준 단음절어표가 친숙성과 빈도가 낮은 음소를 포함하지 않았으므로 본 연구에서 제시한 한국어 독화소 체계를 보완해야 할 점으로 우선/ㄹ///ㅉ/,//TI/, /개/,/T//,///에 대한 반응음소군을 확인해야 할 필요가 있다. 이때 음소 균형, 일상회화체에서의 빈도 및 친숙도 등 기존의 단음절어표와 동일한 기준으로 자극을 선정 하고 제시해야 할 것이다. 특히 중성모음 / 저/는 다른 모음의 반응 음소군에 거의 나타나지 않았으므로 / 기/처럼 다른 반응음소의 독 화소군에 포함되거나 또는 / 기/처럼 독자적으로 독화소를 구성할 가능성이 있다./月/와/게/에 대해서는 현대 음운체계에 / / / 와/게/ 가 합류하면서////와 / /\#/, /개/와 / 게/ 간의 구별이 사라지고, 갈수 록 발음의 독자성을 잃고 있는 등(Lee, 2012) 구별실익이 없는 것으 로 볼 수 있으므로 향후 이론적인 정리가 이루어지는 것으로 충분 할 것이다. /새/의 경우에는 중성 독화소군 / 나, 니/에 대한 반응음 소로서 포함되었는데, /새/에 대한 반응음소군 또한 확인하여 /과, 기, 내/가 하나의 독화소군을 형성하는지 확인해야 할 필요가 있다.

본 연구결과는 모음에 따라 특정 독화소군에 대한 독화 난이도 가 달라질 수 있으므로 독화 교육에 있어 보다 위계적인 교육 및 훈 련 계획이 수립될 수 있는 가능성을 시사한다. 또한 한국표준 단음 절어표는 청각검사를 위한 도구로 개발되었음에도 다양한 자모음 맥락을 반영함에 따라 독화소 체계에 따른 전반적인 독화 능력을 측 정하는 도구로도 활용할 수 있는 가능성을 갖고 있다고 할 수 있다.

\section{REFERENCES}

Auer, E. T., \& Bernstein, L. E. (1997). Speechreading and the structure of the lexicon: computationally modeling the effects of reduced phonetic distinctiveness on lexical uniqueness. The Journal of the Acoustical Society of America, 102, 3704-3710.

Auer, E. T., Bernstein, L. E., Waldstein, R. S., \& Tucker, P. E. (1997). Effects of phonetic variation and the structure of the lexicon on the uniqueness of words. Proceedings of the ESCA/ESCOP Workshop on Audio-Visual Speech Processing, Rhodes, Greece, 21-24.

Benguerel, A. P., \& Pichora-Fuller, M. K. (1982). Coarticulation effects in lipreading. Journal of Speech, Language, and Hearing Research, 25, 600-607.
Bernstein, L. E., Tucker, P. E., \& Demorest, M. E. (2000). Speech perception without hearing. Perception \& Psychophysics, 62, 233-252.

Binnie, C. A., Jackson, P. L., \& Montgomery, A. A. (1976). Visual intelligibility of consonants: a lipreading screening test with implications for aural rehabilitation. Journal of Speech and Hearing Disorders, 41, 530-539.

Burnham, D., Campbell, R., Away, G., \& Dodd, B. J. (2013). Hearing eye II: the psychology of speechreading and auditory-visual speech. East Sussex: Psychology Press.

Byun, S. W. (2001). Frequencies of Korean phonemes and reliability of Korean phonetically balanced word lists. Korean Journal of Otolaryngology-Head and Neck Surgery, 44, 485-489.

Byun, S. W., Chung, S. M., Kim, H. S., \& Go, Y. M. (2005). A survey of phonetically balanced words lists used in training hospitals in Korea. Korean Journal of Otolaryngology-Head and Neck Surgery, 48, 1086-1090.

Chen, T. (2001). Audiovisual speech processing. IEEE Signal Processing Magazine, 18, 9-21.

Chen, T., \& Rao, R. R. (1998). Audio-visual integration in multimodal communication. Proceedings of the IEEE, 86, 837-852.

Cohen, M. M., \& Massaro, D. W. (1993). Modeling coarticulation in synthetic visual speech. In N. M. Thalmann \& D. Thalmann (Eds.), Models and techniques in computer animation (pp. 139-156). Tokyo: Springer Japan.

De Filippo, C. L., \& Sims, D. G. (1988). New reflections on speechreading. The Volta Review, 90, 1-313.

Dodd, B., \& Campbell, R. (1987). Hearing by eye: the psychology of lip-reading. London: Lawrence Erlbaum Associates.

Erber, N. P. (1974). Visual perception of speech by deaf children: recent developments and continuing needs. Journal of Speech and Hearing Disorders, 39, 178-185.

Fisher, C. (1968). Confusions among visually perceived consonants. Journal of Speech and Hearing Research, 11, 796-804.

Grant, K. W., Walden, B. E., \& Seitz, P. F. (1998). Auditory-visual speech recognition by hearing impaired subjects: consonant recognition, sentence recognition, and auditory-visual integration. Journal of the Acoustical Society of America, 103, 2677-2690.

Hiki, S., \& Fukuda, Y. (1997). Negative effect of homophones on speechreading in Japanese. Proceedings of the ESCA Workshop on Audio-Visual Speech Processing: Computational \& Cognitive Science Approaches, Rhodes, Greece, $327-330$

Holden, E. J., \& Owens, R. (2000). Visual speech recognition using cepstral images. Proceedings of IASTED International conference on Signal and Im- 
age Processing, Las Vegas, NV, 331-336.

Jackson, P. L. (1988). The theoretical minimal unit for visual speech perception: visemes and coarticulation. The Volta Review, 90, 99-115.

Jeffers, J., \& Barley, M. (1971). Speechreading (lipreading). Springfield, IL: Charles C. Thomas.

Kim, J. H. (1992). An analysis of the factors constituting speechreading skill (Doctoral dissertation). Daegu University, Daegu, Korea.

Kim, J. H. (2005). A study on development of Korean standardized speechreading skill test (1). Journal of Speech and Hearing Disorders, 14, 23-41.

Kim, J. H. (2016). A study of the validity of the Korean Speech-Reading Skill test. Journal of Speech-Language \& Hearing Disorders, 25, 57-66.

Kim, J. S., Lim, D. H., Hong, H. N., Shin, H. W., Lee, K. D., Hong, B. N., \& Lee, J. H. (2008). Development of Korean Standard Monosyllabic Word Lists for Adults (KS-MWL-A). Audiology and Speech Research, 4, 126-140.

Kim, Y. W. (1993). Effectiveness of speechreading cues for hearing impaired children. Korean Journal of Special Education, 57, 69-108.

Kim, Y. W. (1997). A study of the minimal lip-reading units in Korean phonemes. Korean Journal of Special Education, 14, 55-72.

Kricos, P. B., \& Lesner, S. A. (1982). Differences in visual intelligibility across talkers. The Volta Review, 84(4), 219-225.

Kuk, M. K. (1998). The effect of lipreading program on a hearing-impaired adult's lipreading. Communication Disorders, 21, 107-118.

Kuk, M. K., \& Kang, A. O. (1997). The effect of the lipreading programs on hearing-impaired children's lipreading and voice. Korean Journal of Special Education, 5, 99-122.

Lamoré, P. J., Huiskamp, T. M., van Son, N. J., Bosman, A. J., \& Smoorenburg, G. F. (1998). Auditory, visual and audiovisual perception of segmental speech features by severely hearing-impaired children. Audiology, 37, 396-419.

Leaner, S. A., Sandridge, S. A., \& Kricos, P. B. (1987). Training influences on visual consonant and sentence recognition. Ear and Hearing, 8, 283-287.

Lee, J. H. (2012). Standard pronunciation and real pronunciation of Korean. Seoul: Acanet.

Lee, K. S., Seok, D. I., Kuk, M. K., Kang, C. U., Lee, S. H., Park, S. H., ... \& Park, H. J. (2006). Language instruction and therapy method for deaf childhood. Daegu: Daegu University.

Lee, K. S., \& Kim, J. H. (1991). A review on primary factors of speechreading skill. Journal of Daehan Special Education Association, 12, 23-49.

Lee, S. C. (2010). Comparison of speechreading abilities of adults with normal hearing and with hearing impairment (Doctoral dissertation). Nazarene University, Cheonan, Korea.
Lesner, S. A., \& Kricos, P. B. (1981). Visual vowel and diphthong perception across speakers. Journal of the Academy of Rehabilitative Audiology, 14, 252258.

Lidestam, B., \& Beskow, J. (2006). Visual phonemic ambiguity and speechreading. Journal of Speech, Language, and Hearing Research, 49, 835-847.

Lim, Y. R., \& Sim, H. S. (2016). The effect of the speechreading telepractice intervention using smartphone on speechreading ability of young deaf adults. Korean Journal of Special Education, 15, 125-154.

Mohammed, T., Campbell, R., MacSweeney, M., Milne, E., Hansen, P., \& Coleman, M. (2005). Speechreading skill and visual movement sensitivity are related in deaf speechreaders. Perception, 34, 205-216.

Montgomery, A. A., \& Jackson, P. L. (1983). Physical characteristics of the lips underlying vowel lipreading performance. The Journal of the Acoustical Society of America, 73, 2134-2144.

Montgomery, A. A., Walden, B. E., \& Prosek, R. A. (1987). Effects of consonantal context on vowel lipreading. Journal of Speech, Language, and Hearing Research, 30, 50-59.

O’Neill, J. J., \& Oyer, H. J. (1981). Visual communication for the hard of hearing. Englewood Cliffs, NJ: Prentice-Hall.

Owens, E., \& Blazek, B. (1985). Visemes observed by hearing-impaired and normal-hearing adult viewers. Journal of Speech, Language, and Hearing Research, 28, 381-393.

Park, H., Han, S., Choi, J., Sim, S., Seo, Y., \& Jang, H. (2016). The relationship between vocabulary knowledge and speech perception in school-age children using cochlear implants. Communication Sciences \& Disorders, 21, 488-501.

Park, M. K., Lee, J. H., Kwon, H. S., Im, G. J., Woo, J. S., Lee, H. M., .. \& \& Chae, S. W. (2007). A study for the acoustic characteristics of PB word list according to frequency. Korean Journal of Otolaryngology-Head and Neck Surgery, 50, 480-485.

Park, S. L. (1999). A study on the frequencies of consonants in adult conversational Korean (Master's thesis). Ewha Womans University, Seoul, Korea.

Summerfield, Q. (1987). Comprehensive account of audio-visual speech perception. In B. Dodd \& R. Campbell (Eds.), Hearing by eye: the psychology of lip-reading (pp. 3-51). London: Lawrence Erlbaum.

Tye-Murray, N. (2014). Foundations of aural rehabilitation: children, adults, and their family members. Stamford, CT: Nelson Education.

Walden, B. E., Erdman, S. A., Montgomery, A. A., Schwartz, D. M., \& Prosek, R. A. (1981). Some effects of training on speech recognition by hearingimpaired adults. Journal of Speech, Language, and Hearing Research, 24, 


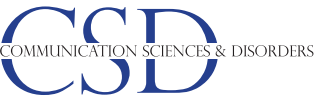

207-216.

Walden, B. E., Prosek, R. A., Montgomery, A. A., Scherr, C. K., \& Jones, C. J. (1977). Effects of training on the visual recognition of consonants. Journal of Speech, Language, and Hearing Research, 20, 130-145.

Watson, C. S., Qiu, W. W., Chamberlain, M. M., \& Li, X. (1996). Auditory and visual speech perception: confirmation of a modality-independent source of individual differences in speech recognition. The Journal of the
한국표준 단음절어표를 이용한 한국어 독화소 체계 분석 - 최재희 외

Acoustical Society of America, 100, 1153-1162.

Woll, B. (2012). Speechreading revisited. Deafness \& Education International, 14, 16-21.

Wozniak, V. D., \& Jackson, P. L. (1979). Visual vowel and diphthong perception from two horizontal viewing angles. Journal of Speech, Language, and Hearing Research, 22, 354-365. 


\section{국문초록}

\section{한국표준 단음절어표를 이용한 한국어 독화소 체계 분석}

최재희 ${ }^{\prime}$ 윤건석 ${ }^{1}$ 류혜수 ${ }^{1} \cdot$ 장현숙 ${ }^{2}$

'한림대학교 일반대학원 언어병리청각학과, ${ }^{2}$ 한림대학교 언어청각학부 청각언어연구소

배경 및 목적: 한국어 독화소 체계 분석에 관한 기존의 연구들은 한정된 음소들을 조합하여 이루어짐으로써 일상회화체의 다양한 특 성들을 반영하지 못한 점이 있다. 이에 본 연구는 일상회화체 내 음소 출현율을 반영한 한국표준 단음절어표 일반용(Korean Standard Monosyllabic Word List for Adults, KS-MWL-A)을 사용하여 독화검사를 실시하고, 한국어의 독화소 체계를 초성·중성·종성별로 분 석하는 데 목적이 있다. 방법: 남녀 화자 2명이 단음절어표를 자연스럽게 발화하는 모습을 녹화하여 성인 32명을 대상으로 음성 없이 독화검사를 실시하고, 단어 정반응률, 음소 정반응률, 반응음소 출현율을 구하였고, 음소 정반응률을 비교하기 위해 일원분산분석을 실시하였다. 초성·중성·종성 혼동 행렬을 통해 반응음소군을 확인하고, 누적 정반응률 $60 \%$ 를 기준으로 독화소군을 결정하였다. 결 과: 연구결과, 단어 정반응률은 $13.00 \%$ 였으며, 음소 정반응률은 초성 $19.04 \%$, 중성 $48.26 \%$, 종성 $44.77 \%$ 로 초성이 중성, 종성보다 유의

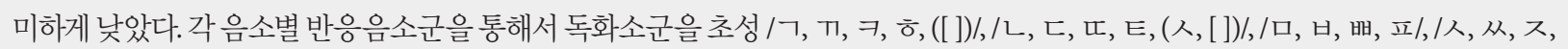

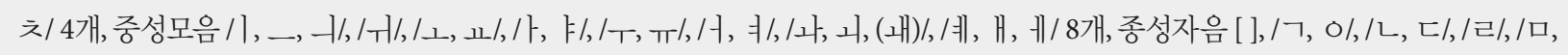
비 5 개로 분류하였다. 논의 및 결론: 한국어 초성자음과 종성자음의 독화소 체계에 미치는 중성모음의 영향력을 확인하였으며, 또한 종성의 유무에 대한 민감성이 종성 독화소 체계에 영향을 미치는 것으로 나타났다.

핵심어: 독화, 독순, 독화소, 한국어 독화소 체계, 한국표준 단음절어표

\section{참고문헌}

국미경(1998). 청각장애성인의 독화훈련 프로그램 적용효과. 난청과 언어장애, 21, 107-118.

국미경, 강애옥(1997). 독화지도 프로그램이 청각장애아의 독화 및 발성에 미치는 효과. 특수교육학연구, 5, 99-122.

김영욱(1993). 청각장애아의 독화 단서에 관한 연구. 한국특수교육학회, 57, 69-108.

김영욱(1997). 한국어 음소의 최소 독화 단위 연구. 특수교육논총, 14, 55-72.

김종현(1992). 말읽기 기능의 구인분석. 대구대학교 대학원 박사학위논문.

김종현(2005). 국어표준화독화기능검사 개발을 위한 연구(1). 언어치료연구, 14, 23-41.

김종현(2016). 국어 말읽기 기능 검사의 타당성 연구. 언어치료연구, 25, 57-66.

김진숙, 임덕환, 홍하나, 신현욱, 이기도, 홍빛나, 이정학(2008). 한국표준 일반용 단음절어표 개발. 청능재활, 4, 126-140.

박무균, 이장혁, 권혁성, 임기정, 우정수, 이흥만, 황순재, 채성원(2007). 어음청력검사 어음표의 주파수별 음향학적 특성에 관한 연구. 대한이비인후과 학회지, 50, 480-485.

박서린(1999). 성인의 일상적인 대화에서 나타나는 말소리 출현빈도 연구. 이화여자대학교 대학원 석사학위논문.

박혜진, 한성아, 최재희, 심상용, 서영란, 장현숙(2016). 학령기 인공와우 착용 아동의 어휘력과 말지각 상관성. 언어청각장애연구, 21, 488-501.

변성완(2001). 한국어의 발음 음소별 빈도로 본 한국어 PB Word의 타당성. 대한청각학회지, 44, 485-489.

변성완, 정성민, 김한수, 고영민(2005). 전국의 수련 병원에서 사용하고 있는 한국어 단음절어 음표의 실태 및 어음 빈도 분석. 대한이비인후과학회지,

48, 1086-1090.

이규식, 석동일, 국미경, 강창욱, 이상희, 박상희, 윤미선, 신혜정, 박희정(2006). 청각장애아동 언어지도와치료방법. 대구: 대구대학교출판부.

이규식, 김종현(1991). 독화기능의 일차적 요소에 대한 고찰. 대한특수교육학회지, 12, 23-49.

이성춘(2010). 건청성인과 청각장애성인의 독화능력 비교. 나사렛대학교 대학원 박사학위논문.

이진호(2012). 한국어의 표준 발음과 현실 발음. 서울: 아카넷.

임예람, 심현섭(2016). 스마트폰을 이용한 원격 독화 중재가 청년층 청각장애인의 독화 능력에 미치는 영향. 특수교육, 15, 125-154. 